\title{
DIE GROEI VAN 'N WES-EUROPESE GEMEENSKAP EN VAN 'N GEMEENSKAPLIKE REGSTELSEL.
}

Behalwe die gemeenskapsplanne wat nie verwesenlik is nie en die Vryhandelsreëling tussen die Skandinawiese Lande, Groot Brittanje, Oostenryk, Switserland en Portugal wat nog slegs in ontwerp bestaan, is daar reeds die volgende gemeenskaplike organe vir WesEuropa of sekere belangrike Wes-Europese lande, naamlik:

1. Die Wes-Europese Unie met 'n gemeenskaplike vergadering vir onderlinge raadpleging, aangevul deur 'n Raad van Buitelandse Ministers en Gesante van die sewe lid-state.

2. Die Organisasie vir Europese Ekonomiese Saamwerking, met sewentien lede waarvan die Raad bindende besluite vir die lidstate kan neem. Dit het verskeie geassosieerde liggame soos die Europese Konferensie van Ministers vir Vervoer en Verkeer.

3. Die Europa-raad is slegs van belang vir sover dit ' $n$ algemene kanaal skep vir onderhandelinge en reeds en- kele konvensies voorberei het, soos die Europese Konvensie vir Menseregte.

4. Beklee met supra-nasionale gesag is die verskillende internasionale liggame van die ses Sentraal-Europese state, nl. die Gemeenskap vir Steenkool en Staal, die Ekonomiese Gemeenskap en die Atoomgemeenskap. Die tweede van bogenoemdes is bedoel om 'n gemeenskaplike mark in die algemeen te skep, en vir die gemeenskap as geheel is daar reeds wetgewende, uitvoerende en regterlike organe voorsien. Dit het ook 'n eie finansiële apparaat.

Afgesien van die gemeenskaplike Romeins-regtelike kodifikasie-grondslag van die algemene Europese reg, is in die afgelope tyd reeds 'n groot mate van regsgelykheid bewerk deur multilaterale en bilaterale verdrae.

Maar bogenoemde gemeenskappe het buitengewoon baie bygedra tot 'n gemeenskaplike regsreëling vir die ses deelnemende state, nie alleen in die gevalle waar die gemeenskapsorgane 
self algemeen-geldige regsreelinge tref nie, maar ook waar hulle alleen rigsnoere gee vir die optrede van die deelnemende state, nl. Nederland, Luxemburg, België, Frankryk, Duitsland en Italië.

Veral die ekonomiese gemeenskap of Tolunie is in hierdie verband van belang, omdat dit bedoel om mettertyd vryhandel tussen die genoemde state te bewerkstellig, insluitende vryheid in die uitruiling van kapitaal, arbeid en handelsware.

Verwag word verder dat deur die werking van die gemeenskaplike geregshof en andersins, die gemeenskaplikEuropese regsbeginsels, soos in die ou natuurreg en handelsreg beliggaam, weer geleidelik meer positiewe erkenning sal verkry namate die gemeenskapsgees aangroei.

In hierdie verband is die volgende uitspraak van J. Bärmann in Juristenzeitung van 18 Sept. 1959, bl. 559, insiggewend en "Zeitgemäsz":

Hy bedoel hierin om aan te dui dat die groeiende internasionale reg van ons tyd nie in die eerste plek van wets- tekste afhanklik is nie; dat wetstekste inteendeel maar ermbarmlike poginge is om geldende regsvoorstellinge aan te dui en dan gaan hy voort:

„Die nationale Kodifikationsbewegung des ausgehenden 18., des. 19. und des. 20 Jahrhunderd hat es im Grunde nicht vermocht, diese deutschrechtliche Auffassung vom Sinne des Rechtes zu wiederlegen; sie hat vor allem nicht das Bestehen einer supranationalen Ordnung im Bereich von Handel, Wirtschaft und Verkehr aufzulösen vermocht. Die fruchtbare, aber letzten Endes unendliche und unlösbare Aufgabe der wissenschaftlichen Rechtsvergleichung wird sich weniger als bisher - da sie a-historisch betriëben wurde --- der analytischen Untersuchung der Gegensätzlichkeit, als vielmehr - unter Verwertung der institutionengeschichtlichen Ausgangspunkte, vor allem vor der Kodifikationsperiode - einer synthetischen, konstruktiven Darstellung der Strukturgleichheit hingeben müssen". 